\title{
Association between urban green space and the risk of Alzheimer's disease: A longitudinal study
}

\section{Yoosun Cho}

Seoul National University Hospital

\section{Seulggie Choi}

Seoul National University Hospital

\section{Sumin Seo}

Sungkyunkwan University - Suwon Campus

Gyeongsil Lee

Seoul National University Hospital

Sang Min Park ( $\nabla$ smpark.snuh@gmail.com)

Seoul National University Hospital https://orcid.org/0000-0002-7498-4829

\section{Research article}

Keywords: urban green space, urban planning policy, Alzheimer's disease, cohort study, Republic of Korea

Posted Date: June 12th, 2020

DOI: https://doi.org/10.21203/rs.3.rs-33917/v1

License: (c) (1) This work is licensed under a Creative Commons Attribution 4.0 International License. Read Full License 


\section{Abstract}

\section{Backgrounds}

Although studies have demonstrated the beneficial effects of green spaces on general well being, the benefits of urban green spaces on Alzheimer's disease (AD) are still unclear. In this retrospective cohort study, we sought to ascertain the connection between the presence of green spaces in urban environments and risk of $A D$.

\section{Methods}

The study sample comprised 294,983 participants, aged 40-74 years, and was derived from the Korean National Health Insurance Service National Sample Cohort. We used data of area $\left(\mathrm{m}^{2}\right)$ and amount of artificial parks in 2005, provided by the Ministry of Land, Infrastructure and Transport. Starting from 2009, after removing those who received a dementia diagnosis within 1-3 years of gathering the index data, participants received follow-up AD testing. The Cox proportional-hazards model was utilized to establish the adjusted hazard ratios (aHRs) and 95\% confidence intervals (Cls) of AD risk, based on the amount of urban green space area.

Results

Compared to the quartile with the least amount of green space, participants in the highest urban space quartile had a reduced risk of receiving an AD diagnosis (aHR $0.84,95 \% \mathrm{Cl} 0.72-0.99$ ). The mediating effect of green space presence on AD was stronger among those in higher household income brackets (aHR $0.80,95 \% \mathrm{Cl} 0.65-0.99$ ), with more comorbidities (aHR 0.78, 95\% Cl 0.64-0.96), and without disabilities (aHR 0.82, 95\% Cl 0.69-0.97).

\section{Conclusions}

Living in urban areas with increased green space coverage may ultimately result in a lower risk of being diagnosed with $A D$. Urban planning strategies capable of boosting the total coverage of urban green space may assist in reducing $A D$ risk.

\section{Backgrounds}

Among elderly populations, dementia is considered to be one of the primary causes for increased risk of debilitating conditions in later life, and it has now come to signify one of the biggest challenges for health systems and social care initiatives around the world (1). In 2015, it was estimated that approximately 47 million people suffered from dementia (2), and this number is expected to triple by 2050 (3). Korea, which transitioned from an old society to a very old society in 2018, has a higher prevalence of dementia than most other Asian and Western countries. Alzheimer's disease (AD) is one of the most common types of dementia, and the rate of $A D$ is expected to rise as elderly adults come to represent a greater proportion of the population. Therefore, it is essential for researchers to pursue research on prevention to identify 
risks and protective factors that can be altered in order to reduce the risk of dementia (4). According to the Alzheimer's Association, there is sufficient enough evidence to conclude that regular exercise, management of cardiovascular risk factors (obesity, diabetes, smoking, and hypertension), and cognitive training are capable of reducing risks associated with cognitive decline (5). Based on these findings, a new focus on the importance of strategies to prevent incidence of $A D$ within living environments has emerged.

Green space is recognized as a flexible fixture of the modern metropolitan environment often associated with the health of inhabitants. Studies have shown that people who reside in urban settings enjoy more healthy lifestyles, regardless of their demographic or economic status, when green space is more readily available $(6,7)$. Due to increased urbanization, people are facing the reality of fewer green spaces in their living environments, which may negatively affect their health (6). It is believed that green space could reduce cardiovascular and premature overall mortality, while also improving mental health and overall cognitive functions (7). The presence of green spaces within local neighborhood environments is associated with decreased rates of poor health in self-reporting surveys (8), as well as all causes of mortality, respiratory disease, and circulatory diseases (9). According to a study from New Zealand, neighborhood green space was linked to increased cardiovascular and cognitive function, independent of individual risk factors (10). Prior studies have examined the connection between green spaces in urban settings and general health or health behaviors related to dementia. However, few studies have researched how green spaces affect the risk of $A D$ diagnoses in urban areas.

Based on the evidence of the positive benefits of green spaces on physical, mental, physical, cognitive, and social health, which would be considered critical elements of $A D$ risk prevention, we sought to look at the prevalence of green space in urban areas and whether it can be an indicator for $A D$ risk.

\section{Materials And Methods}

\section{Study population}

The research sample was obtained from the database of the National Sample Cohort of the Korean National Health Insurance Service (NHIS-NSC). The Sample Cohort database comprised beneficiaries' sociodemographic information; medical claims dataset, including diagnostic information from the 10th revision of the International Classification of Disease (ICD-10); admission, treatment; and the partner members' National Health Screening datasets. The information for the national health screenings was created by the NHIS and provides information through a health check-up database for all Korean inhabitants from 2002 to 2013; it also contains information on biological factors health exams and health habits. Korea's NHIS requires Koreans to join the national health insurance scheme, which covers nearly all available health services (11), including semiannual check-ups for people 40 years or older (12). Multiple previous epidemiological trials have utilized the NHIS database, and outlines confirming their legitimacy have been defined in detail elsewhere $(13,14)$. 
We extracted our data from data obtained in 2005 for 476,985 participants from seven cities in Korea. Of these, 294,983 participants aged $<40$ or $>74$ years were excluded. We also excluded 848 participants without green space values or readily available total land area data, as offered by the Ministry of Land, Infrastructure, and Transport (MOLIT). Then, 980 and 823 respondents were excluded due to death or diagnosis of any form of disease prior to the indexing date. The study population was comprised of 179,351 respondents. Starting on 1 January 2009, the respondents were followed until the date they first received AD treatment, their death, or 31 December 2013.

\section{Ethical Considerations}

Seoul National University Hospital's institutional review board approved this study (IRB number: E-1803045-928). They removed the request for informed approval, as the NHIS-NSC database is anonymized and follows rigorous confidentiality rules.

\section{Key Variables}

MOLIT provided land category statistics for things such as parks and green spaces. The 2005 data included total area $\left(\mathrm{m}^{2}\right)$ and the amount of artificial parks and open green spaces built as government projects for purposes of safety and recreation.

We did not include natural green space as defined in our study, such as fields, mountains, and forests, into urban green space. Seven Korean metropolitan cities have been divided to 72 administrative districts that match the metropolitan areas where participants live. The area of districts areas varied between $2.8 \mathrm{~km}^{2}$ and $755.0 \mathrm{~km}^{2}$, with a mean of $55.1 \mathrm{~km}^{2}$ (standard deviation, SD $=79.9 \mathrm{~km}^{2}$ ). The coverage of green spaces in each urban district was defined as a proportion (\%). All green spaces were classified into quartiles with specific threshold values $0.0-0.34,0.34-0.92,0.94-2.33,2.38-15.3$. In our study, we defined Alzheimer's Disease (AD) based on a positive AD diagnosis (ICD-10 codes F00, G30) with the prescription of dementia-related drugs, including donepezil, galantamine, rivastigmine, and memantine (15).

\section{Statistical analysis}

The Cox proportional-hazard model was utilized to ascertain adjusted hazard ratios (aHRs) and 95\% confidence intervals (Cls) for AD risk. We also conducted a stratified analysis of the connection between green spaces in urban settings with AD based on age, gender, physical activity, household income, comorbidity, and disability subgroups. Finally, we conducted an analysis of sensitivity to the effects of green spaces in urban environments on $A D$; however, participants who received a dementia diagnosis within 5 years of the indexing date were excluded. The statistical significance was treated as $P<.05$ from a two-sided approach. We collected data using SAS 9.4 (SAS Institute, Cary, NC, USA) and statistical analysis with STATA 13.0 (Stata Corp LP, College Station, TX, USA).

\section{Results}


Table 1 offers insights into the characteristics of the study participants. The average green space value is $1.67 \%$ overall, and the individual values of the four quartiles, from smallest to greatest, are $0.17 \%, 0.64 \%$, $1.58 \%$, and $4.54 \%$, respectively. The number of participants who received health screenings was 80,170 , representing $44.7 \%$ of all participants. The group with the highest household income tended to reside in neighborhoods containing larger amounts of green space available $(13,613,14,854,14,997$, and 15,935 participants from the lowest to the highest quartile). On the other hand, the group with the lowest household income tended to live in areas with less urban green space $(8,204,7,802,7,120$, and 6,157 participants from the lowest to the highest quartile).

Table 2 illustrates the reduced risk associated with green space coverage of developing AD inversely. By comparison to those in the first (smallest) quartile, those in the second, fifth, and fourth (largest) quartiles tended to experience a decreased risk of AD (aHR 0.98, 95\%, Cl 0.84-1.14; aHR 0.96, 95\%, Cl 0.82-1.11; aHR $0.84,95 \%, \mathrm{Cl} 0.72-0.99$, respectively). The risk of $A D$ tended to be reduced with increasing green space coverage with significance as well ( $p$ for trend $=0.045$ ).

Table 3 shows a stratified analysis of the impact urban green spaces have on AD based on the subgroups of age, sex, household income, comorbidity, and disability. When comparing the respondents in the first (smallest) green space quartile to other quartiles, those with greater household income (aHR $0.80,95 \%, \mathrm{Cl} 0.65-0.99, \mathrm{p}$ for trend $=0.027$ ), with more comorbidities (aHR 0.78,95\%, Cl 0.64-0.96, p for trend $=0.021$ ), and those without any impairments (aHR 0.82,95\%, Cl 0.69-0.97, p for trend $=0.022$ ) tended to have decreased risk of $A D$. An inverse relationship between the presence of green space and the prevalence of $A D$ was discovered during the subgroup analysis based on age and sex, but without significance.

Table 4 reveals the impact of urban green spaces on $A D$ prevalence in participants after receiving dementia diagnoses within 5 years of the indexing date. After excluding participants who received diagnoses of dementia within 5 years after the indexing date, the risk of $A D$ tended to be consistent (aHR $0.83,95 \%, \mathrm{Cl} 0.69-1.00, p$ for trend $=0.038$ ). Supplement Table 1 represents the association of urban green space on $A D$ among individuals who underwent health screening examinations. We found a trend of reduced $A D$ risk with increasing green space coverage, but with no significance (aHR $0.81,95 \%, \mathrm{Cl}$ $0.62-1.04, p$ for trend $=0.139$ ). After adjusting all covariates, including biological factors and lifestyle behaviors, age, gender, household income, housing region, comorbidity, BMI, total cholesterol, blood pressure, fasting blood sugar, smoking status, level of physical exercise, and alcohol intake were still not significant, but the trend towards lower danger of AD (aHR $0.81,95 \%, 0.62-1.06, p$ for trend $=0.161$ ) was maintained.

\section{Discussion}

We have shown that participants in neighborhood settings with a greater degree of green space available have less risk of developing AD. As far as we know, ours is the first study to show how significant the relationship between residential green space and $A D$ risk is for general populations in Asia. 
Some modifiable risk factors for AD, physical inactivity, depression, and social isolation in late life (16), could be attenuated for people living with green space. Several feasible theories may support the preventive effects of the presence of green space in urban settings on AD risk, improving physical, mental, and cognitive health, which are known attenuators of AD risk. Physical activity is also shown to increase when greener surroundings are readily available (17-19). Green space availability in neighborhoods could also promote exercise, such as walking, for middle-age and older adults (17). Respondents living in low proximity to local green spaces were shown to be less prone to visiting green spaces than respondents living in close proximity to green spaces (20). Some Western studies have previously demonstrated that activity levels increase for those living in neighborhoods with larger areas of green space $(21,22)$. Likewise, for Korea, increased levels of physical activity were linked to areas with more public parks (18). Many prospective studies have shown that the likelihood of developing AD significantly decreases in participants who engage in exercise activities more often (23-28). Another 17year-long study of elderly Japanese subjects has also shown physical activity prevent AD (29). Recently, a randomized, controlled study of elderly people who had not been diagnosed with dementia revealed that exercise could increase hippocampal volume and enhance overall cognitive function (30). Individuals who were more physically active exhibited lower levels of $A \beta$ deposits in $A \beta$ screenings, which are associated with the clinical conditions of AD patients (31).

The neighborhood environment, as a mechanism for urban green spaces to benefit mental health, has been introduced (32-34). It has also been shown that access to green spaces over the long term potentially plays a protective role, benefiting mental health and alleviating anxiety and depression (35). People residing in environments with less access to green spaces reported more feelings of solitude and lack of social connection compared to respondents who lived in neighborhoods with more green space access (36). Green space was directly associated with reduced levels of stress among adults in older age groups (37) and could alleviate the negative health effects of stress (38). There was a protective association between green spaces and depression and suicide predictors, which are potential indicators of future AD risks, according to the study on the Korean population (39). According to two meta-analyses, depression can significantly increase the risk of a dementia diagnosis, by as much as twofold $(40,41)$. Several studies also suggested that symptoms of depression were associated with AD risk (42-44). There is a neuropathological correlation between dementia and depression, and this can be observed via alterations in glucocorticoid steroids and hippocampal atrophy, increased deposits of $\beta$-amyloid plaques, inflammatory changes, and deficits of nerve growth factors or regulators like neurotrophins (45). According to these findings, it is plausible to assume more urban green spaces are necessary for assisting the elderly population, who are among the most vulnerable groups when it comes to certain mental health issues that are known $A D$ risks.

Urban green space may play a protective role for cognitive function, which could in turn reduce the overall risk of AD. A greater likelihood of cognitive decline and dementia has been linked to a lower proportion of nearby green spaces and private garden spaces (46). Neighborhoods making public parks available for residents throughout their lives may help reduce the rate of mental impairment residents may be more likely to experience at a later stage in their lives (47). Parks in urban environments may act as a more 
stimulating space from a cognitive perspective compared to other types of green spaces, such as green spaces in non-urban settings (48). In addition, greenness in neighborhood areas can facilitate social relationships, develop social cohesion, and ultimately create a sense of solidarity among community members (49), which could also benefits individuals' cognitive function. In a Taiwanese cohort study with 11 years of follow-up, it has been reported that social activities share an inverse relationship with a decline in scores on a Mental Status Questionnaire (50). Increased pursuit of physical, intellectual, and social activities in addition to increased cognitive capacity have been linked with a decreased risk of receiving a diagnosis of dementia (51). There are complex and heterogeneous mechanisms associated with how green spaces affect cognitive ability. The protective effect from greenness on physical, mental health, and social cohesion may result in improved cognitive health and possible prevention of AD.

\section{Limitations and Strengths}

Several limitations should be considered in our study. First, we limited the type of urban green spaces to urban parks, excluding natural fields and wooded areas, as we decided to determine the effect of artificial green spaces. Second, due to the lack of data, the residential district codes of our participants did not exactly match to addresses of respondents in order to preserve anonymity. Thus, NHIS-NSC residential district codes are unlikely to correlate with the addresses gathered for green space data, including exact addresses and GIS maps. Nevertheless, there are a couple of studies that have used participants' district codes and environmental data, and we adopted the same methodological design $(39,52)$. Third, we had to rely on prescription and diagnostic codes for medications, as we were unable to access dementiarelated medical chart documents. However, for patients to receive reimbursement from the NHIS for antidementia drugs, two requirements have to be met; first, they must receive an Mini-Mental State Examination (MMSE) rating of 26 or less; and secondly, they must receive either a Clinical Dementia rating of 1 or higher or a Global Deterioration Scale rating of 3 or greater. ${ }^{17}$ Even though the diagnostic reliability of dementia seems to increase, there is a need for researchers in the future to use medical records to achieve a more accurate findings to complement the results of our study. Finally, cautious interpretation is needed, due to the fact that only a 5-year follow-up period was used to discover the association of green space prevalence and AD diagnoses. Despite limitations, our study also features a number of strong points. First, in contrast to most of previous studies indirectly or directly reported the impacts of physical activity, mental well being, or social cohesion on AD risk, we first discovered the link between green space coverage, a potential candidate for environmental intervention, on the long-term prevalence of AD. Second, we utilized data from a nationwide database of more than 290,000 participants, aged 40-74 aged, from seven metropolitan cities. Third, through a sensitivity analysis, we consolidated the data to determine the effects of urban green spaces on reduced $A D$ risk with a 5-year washout period.

\section{Conclusions}


This study indicates that living in urban areas that feature adequate green spaces may ultimately result in reduced $A D$ risk among adults in middle age, as well as elderly adults. Our findings bolster the position that urban planning policies should be created to utilize urban green spaces to assist in reducing AD. It may be beneficial to create new or additional green spaces in urban environments or to look into developing outdoor activities capable of properly utilizing existing resources to reduce AD risk. Future long-term follow-up studies investigating whether greater urban green spaces actually result in reduced $A D$ risk should be carried out to validate our study's findings.

\section{Declarations}

\section{Ethics approval and participation consent}

This study has been approved by Seoul National University Hospital's institutional review board (IRB number: E-1803-045-928). They removed the request for informed approval, as the NHIS-NSC database is anonymized and observes rigorous confidentiality rules.

\section{Consent for publication}

Not applicable

\section{Availability of data and materials}

The supporting data for this study's findings is available from the Korean National Health Insurance Service (KNHIS) and the Ministry of Land, Infrastructure, and Transport (MOLIT) but restrictions apply to the availability of this data, which was licensed for this study, and so it is not publicly available. However, data is available from the authors, if a reasonable request made, and with permission of KNHIS and MOLIT.

\section{Competing interests}

None of the authors reported any disclosures.

\section{Funding}

This study received funding from the Data Science Research Project 2018 under Seoul National University's Big Data Institute (grant number: 2018-0000) and Seoul National University's Hospital Research Fund (grant number: 04-2018-0370).

\section{Author Contributions}

S.M.P. received full access to all data in the study and accepts full responsibility for the integrity of the data and the accuracy of the analysis. Study concept and design: S.M.P.; acquisition of data: S.C., Y.C., S.M.P.; drafting of the article: Y.C.; analysis and interpretation of data: S.C., Y.C., S.M.P., S.S., G.L.; critical 
revision of the manuscript: S.C. S.S.; administrative, technical, or material support: G.L. All authors have read and agreed to the published version of the manuscript.

\section{References}

1. DALYs GBD, Collaborators H, Murray CJ, Barber RM, Foreman KJ, Abbasoglu Ozgoren A, et al. Global, regional, and national disability-adjusted life years (DALYs) for 306 diseases and injuries and healthy life expectancy (HALE) for 188 countries, 1990-2013: quantifying the epidemiological transition. Lancet. 2015;386(10009):2145-91.

2. Prince MGM, Prina M. The Epidemiology and Impact of Dementia: Current State and Future Trends. Geneva. World Health Organization. 2015.

3. Prince MGM, Prina M. Alzheimer's Disease International. Policy Brieffor Heads of Government: The Global Impact ofDementia 2013-2050. London: Alzheimer's Disease International; 2013.

4. Winblad B, Amouyel P, Andrieu S, Ballard C, Brayne C, Brodaty H, et al. Defeating Alzheimer's disease and other dementias: a priority for European science and society. Lancet Neurol. 2016;15(5):455532.

5. Cognitive Aging. Progress in Understanding and Opportunities for Action. Mil Med. 2015;180(11):1111-3.

6. Nieuwenhuijsen MJ. Urban and transport planning, environmental exposures and health-new concepts, methods and tools to improve health in cities. Environ Health. 2016;15(Suppl 1):38.

7. Nieuwenhuijsen MJ, Khreis H, Triguero-Mas M, Gascon M, Dadvand P. Fifty Shades of Green: Pathway to Healthy Urban Living. Epidemiology. 2017;28(1):63-71.

8. Mitchell R, Popham F. Greenspace, urbanity and health: relationships in England. J Epidemiol Community Health. 2007;61(8):681-3.

9. Mitchell R, Popham F. Effect of exposure to natural environment on health inequalities: an observational population study. Lancet. 2008;372(9650):1655-60.

10. Richardson EA, Pearce J, Mitchell R, Kingham S. Role of physical activity in the relationship between urban green space and health. Public Health. 2013;127(4):318-24.

11. Cheol Seong S, Kim YY, Khang YH, Heon Park J, Kang HJ, Lee H, et al. Data Resource Profile: The National Health Information Database of the National Health Insurance Service in South Korea. Int J Epidemiol. 2017;46(3):799-800.

12. Seong SC, Kim YY, Park SK, Khang YH, Kim HC, Park JH, et al. Cohort profile: the National Health Insurance Service-National Health Screening Cohort (NHIS-HEALS) in Korea. BMJ Open. 2017;7(9):e016640.

13. Kim K, Park SM, Lee K. Weight gain after smoking cessation does not modify its protective effect on myocardial infarction and stroke: evidence from a cohort study of men. Eur Heart J. 2018;39(17):1523-31. 
14. Choi S, Chang J, Kim K, Park SM, Lee K. Effect of Smoking Cessation and Reduction on the Risk of Cancer in Korean Men: A Population Based Study. Cancer Res Treat. 2018;50(4):1114-20.

15. Jeong SM, Shin DW, Lee JE, Hyeon JH, Lee J, Kim S. Anemia is associated with incidence of dementia: a national health screening study in Korea involving 37,900 persons. Alzheimers Res Ther. 2017;9(1):94.

16. Livingston G, Sommerlad A, Orgeta V, Costafreda SG, Huntley J, Ames D, et al. Dementia prevention, intervention, and care. Lancet. 2017;390(10113):2673-734.

17. Astell-Burt T, Feng X, Kolt GS. Green space is associated with walking and moderate-to-vigorous physical activity (MVPA) in middle-to-older-aged adults: findings from 203883 Australians in the 45 and Up Study. Br J Sports Med. 2014;48(5):404-6.

18. Park JY, Shin HK, Choi JS, Oh HS, Choi KH, Park SM, et al. Do People Have Healthier Lifestyles in Greener Environments? An Analysis of the Association between Green Environments and Physical Activity in Seven Large Korean Cities. Korean J Fam Med. 2013;34(1):58-63.

19. Mytton OT, Townsend N, Rutter H, Foster C. Green space and physical activity: an observational study using Health Survey for England data. Health Place. 2012;18(5):1034-41.

20. Coombes $\mathrm{E}$, Jones AP, Hillsdon M. The relationship of physical activity and overweight to objectively measured green space accessibility and use. Soc Sci Med. 2010;70(6):816-22.

21. Cohen DA, McKenzie TL, Sehgal A, Williamson S, Golinelli D, Lurie N. Contribution of public parks to physical activity. Am J Public Health. 2007;97(3):509-14.

22. Librett J, Henderson K, Godbey G, Morrow JR. Jr. An introduction to parks, recreation, and public health: collaborative frameworks for promoting physical activity. J Phys Act Health. 2007;4(Suppl 1):1-13.

23. Abbott RD, White LR, Ross GW, Masaki KH, Curb JD, Petrovitch H. Walking and dementia in physically capable elderly men. JAMA. 2004;292(12):1447-53.

24. Buchman AS, Boyle PA, Yu L, Shah RC, Wilson RS, Bennett DA. Total daily physical activity and the risk of $A D$ and cognitive decline in older adults. Neurology. 2012;78(17):1323-9.

25. Guure CB, Ibrahim NA, Adam MB, Said SM. Impact of Physical Activity on Cognitive Decline, Dementia, and Its Subtypes: Meta-Analysis of Prospective Studies. Biomed Res Int. 2017;2017:9016924.

26. Najar J, Ostling S, Gudmundsson P, Sundh V, Johansson L, Kern S, et al. Cognitive and physical activity and dementia: A 44-year longitudinal population study of women. Neurology. 2019;92(12):e1322-e30.

27. Podewils LJ, Guallar E, Kuller LH, Fried LP, Lopez OL, Carlson M, et al. Physical activity, APOE genotype, and dementia risk: findings from the Cardiovascular Health Cognition Study. Am J Epidemiol. 2005;161(7):639-51.

28. Scarmeas N, Luchsinger JA, Schupf N, Brickman AM, Cosentino S, Tang MX, et al. Physical activity, diet, and risk of Alzheimer disease. JAMA. 2009;302(6):627-37. 
29. Kishimoto H, Ohara T, Hata J, Ninomiya T, Yoshida D, Mukai N, et al. The long-term association between physical activity and risk of dementia in the community: the Hisayama Study. Eur J Epidemiol. 2016;31(3):267-74.

30. Erickson KI, Voss MW, Prakash RS, Basak C, Szabo A, Chaddock L, et al. Exercise training increases size of hippocampus and improves memory. Proc Natl Acad Sci U S A. 2011;108(7):3017-22.

31. Liang KY, Mintun MA, Fagan AM, Goate AM, Bugg JM, Holtzman DM, et al. Exercise and Alzheimer's disease biomarkers in cognitively normal older adults. Ann Neurol. 2010;68(3):311-8.

32. Lee HJ, Lee DK. Do Sociodemographic Factors and Urban Green Space Affect Mental Health Outcomes Among the Urban Elderly Population? Int J Environ Res Public Health. 2019;16(5).

33. Wood L, Hooper P, Foster S, Bull F. Public green spaces and positive mental health - investigating the relationship between access, quantity and types of parks and mental wellbeing. Health Place. 2017;48:63-71.

34. Wu YT, Prina AM, Jones A, Matthews FE, Brayne C, Mrc C. Older people, the natural environment and common mental disorders: cross-sectional results from the Cognitive Function and Ageing Study. BMJ Open. 2015;5(9):e007936.

35. Gascon M, Sanchez-Benavides G, Dadvand P, Martinez D, Gramunt N, Gotsens X, et al. Long-term exposure to residential green and blue spaces and anxiety and depression in adults: A crosssectional study. Environ Res. 2018;162:231-9.

36. Maas J, van Dillen SME, Verheij RA, Groenewegen PP. Social contacts as a possible mechanism behind the relation between green space and health. Health Place. 2009;15(2):586-95.

37. Pun VC, Manjourides J, Suh HH. Association of neighborhood greenness with self-perceived stress, depression and anxiety symptoms in older U.S adults. Environ Health. 2018;17(1):39.

38. van den Berg AE, Maas J, Verheij RA, Groenewegen PP. Green space as a buffer between stressful life events and health. Soc Sci Med. 2010;70(8):1203-10.

39. Min KB, Kim HJ, Kim HJ, Min JY. Parks and green areas and the risk for depression and suicidal indicators. Int J Public Health. 2017;62(6):647-56.

40. Jorm AF. History of depression as a risk factor for dementia: an updated review. Aust N Z J Psychiatry. 2001;35(6):776-81.

41. Ownby RL, Crocco E, Acevedo A, John V, Loewenstein D. Depression and risk for Alzheimer disease: systematic review, meta-analysis, and metaregression analysis. Arch Gen Psychiatry. 2006;63(5):530-8.

42. Gatz JL, Tyas SL, St John P, Montgomery P. Do depressive symptoms predict Alzheimer's disease and dementia? J Gerontol A Biol Sci Med Sci. 2005;60(6):744-7.

43. Saczynski JS, Beiser A, Seshadri S, Auerbach S, Wolf PA, Au R. Depressive symptoms and risk of dementia: the Framingham Heart Study. Neurology. 2010;75(1):35-41.

44. Wilson RS, Barnes LL, Mendes de Leon CF, Aggarwal NT, Schneider JS, Bach J, et al. Depressive symptoms, cognitive decline, and risk of AD in older persons. Neurology. 2002;59(3):364-70. 
45. Byers AL, Yaffe K. Depression and risk of developing dementia. Nat Rev Neurol. 2011;7(6):323-31.

46. Wu YT, Prina AM, Brayne $C$. The association between community environment and cognitive function: a systematic review. Soc Psychiatry Psychiatr Epidemiol. 2015;50(3):351-62.

47. Cherrie MPC, Shortt NK, Mitchell RJ, Taylor AM, Redmond P, Thompson CW, et al. Green space and cognitive ageing: A retrospective life course analysis in the Lothian Birth Cohort 1936. Soc Sci Med. 2018;196:56-65.

48. Cassarino M, O'Sullivan V, Kenny RA, Setti A. Environment and cognitive aging: A cross-sectional study of place of residence and cognitive performance in the Irish longitudinal study on aging. Neuropsychology. 2016;30(5):543-57.

49. Ruijsbroek A, Mohnen SM, Droomers M, Kruize H, Gidlow C, Grazuleviciene R, et al. Neighbourhood green space, social environment and mental health: an examination in four European cities. Int $\mathrm{J}$ Public Health. 2017;62(6):657-67.

50. Glei DA, Landau DA, Goldman N, Chuang YL, Rodriguez G, Weinstein M. Participating in social activities helps preserve cognitive function: an analysis of a longitudinal, population-based study of the elderly. Int J Epidemiol. 2005;34(4):864-71.

51. Marioni RE, Proust-Lima C, Amieva H, Brayne C, Matthews FE, Dartigues JF, et al. Social activity, cognitive decline and dementia risk: a 20-year prospective cohort study. BMC Public Health. 2015;15:1089.

52. Kim HJ, Min JY, Kim HJ, Min KB. Parks and Green Areas Are Associated with Decreased Risk for Hyperlipidemia. Int J Environ Res Public Health. 2016;13(12).

\section{Tables}


Table 1

Descriptive characteristics of study population

\begin{tabular}{|c|c|c|c|c|c|}
\hline & \multirow[t]{2}{*}{ Total } & \multicolumn{4}{|c|}{ Urban green space coverage ${ }^{a}$} \\
\hline & & $\begin{array}{l}\text { First } \\
\text { quartile } \\
\text { (Low) }\end{array}$ & $\begin{array}{l}\text { Second } \\
\text { quartile }\end{array}$ & $\begin{array}{l}\text { Third } \\
\text { quartile }\end{array}$ & $\begin{array}{l}\text { Fourth } \\
\text { quartile (High) }\end{array}$ \\
\hline $\begin{array}{l}\text { Urban green space coverage, } \\
\text { mean (SD), \% }\end{array}$ & $1.67(2.30)$ & $\begin{array}{l}0.17 \\
(0.10)\end{array}$ & $\begin{array}{l}0.64 \\
(0.18)\end{array}$ & $\begin{array}{l}1.58 \\
(0.44)\end{array}$ & $4.54(3.23)$ \\
\hline Participants, N (\%) & $\begin{array}{l}179,351 \\
(100.00)\end{array}$ & $\begin{array}{l}45,864 \\
(25.57)\end{array}$ & $\begin{array}{l}46,476 \\
(25.91)\end{array}$ & $\begin{array}{l}44,554 \\
(24.84)\end{array}$ & $\begin{array}{l}42,457 \\
(23.67)\end{array}$ \\
\hline \multicolumn{6}{|l|}{ Age, years, N (\%) } \\
\hline $40-49$ & $\begin{array}{l}82,974 \\
(46.26)\end{array}$ & $\begin{array}{l}20,041 \\
(43.70)\end{array}$ & $\begin{array}{l}21,740 \\
(46.78)\end{array}$ & $\begin{array}{l}21,450 \\
(48.14)\end{array}$ & $\begin{array}{l}19,743 \\
(46.50)\end{array}$ \\
\hline $50-59$ & $\begin{array}{l}54,324 \\
(30.29)\end{array}$ & $\begin{array}{l}14,006 \\
(30.54)\end{array}$ & $\begin{array}{l}14,092 \\
(30.32)\end{array}$ & $\begin{array}{l}13,004 \\
(29.19)\end{array}$ & $\begin{array}{l}13,222 \\
(31.14)\end{array}$ \\
\hline $60-69$ & $\begin{array}{l}32,781 \\
(18.28)\end{array}$ & $\begin{array}{l}9,123 \\
(19.89)\end{array}$ & $\begin{array}{l}8,386 \\
(18.04)\end{array}$ & $\begin{array}{l}7,847 \\
(17.61)\end{array}$ & 7,425 (17.49) \\
\hline $70-74$ & $\begin{array}{l}9,272 \\
(5.17)\end{array}$ & $\begin{array}{l}2,694 \\
(5.87)\end{array}$ & $\begin{array}{l}2,258 \\
(4.86)\end{array}$ & $\begin{array}{l}2,253 \\
(5.06)\end{array}$ & $2,067(4.87)$ \\
\hline \multicolumn{6}{|l|}{ Sex, N (\%) } \\
\hline Men & $\begin{array}{l}87,673 \\
(48.88)\end{array}$ & $\begin{array}{l}22,238 \\
(48.49)\end{array}$ & $\begin{array}{l}22,885 \\
(49.24)\end{array}$ & $\begin{array}{l}21,812 \\
(48.96)\end{array}$ & $\begin{array}{l}20,738 \\
(48.84)\end{array}$ \\
\hline Women & $\begin{array}{l}91,678 \\
(51.12)\end{array}$ & $\begin{array}{l}23,626 \\
(51.51)\end{array}$ & $\begin{array}{l}23,591 \\
(50.76)\end{array}$ & $\begin{array}{l}22,742 \\
(51.04)\end{array}$ & $\begin{array}{l}21,719 \\
(51.16)\end{array}$ \\
\hline \multicolumn{6}{|l|}{ Household income, N (\%) } \\
\hline First quartile (lowest) & $\begin{array}{l}29,283 \\
(16.33)\end{array}$ & $\begin{array}{l}8,204 \\
(17.89)\end{array}$ & $\begin{array}{l}7,802 \\
(16.79)\end{array}$ & $\begin{array}{l}7,120 \\
(15.98)\end{array}$ & $6,157(14.50)$ \\
\hline Second quartile & $\begin{array}{l}37,778 \\
(21.06)\end{array}$ & $\begin{array}{l}10,295 \\
(22.45)\end{array}$ & $\begin{array}{l}9,978 \\
(21.47)\end{array}$ & $\begin{array}{l}9,067 \\
(20.35)\end{array}$ & 8,438 (19.87) \\
\hline Third quartile & $\begin{array}{l}52,891 \\
(29.49)\end{array}$ & $\begin{array}{l}13,752 \\
(29.98)\end{array}$ & $\begin{array}{l}13,842 \\
(29.78)\end{array}$ & $\begin{array}{l}13,370 \\
(30.01)\end{array}$ & $\begin{array}{l}11,927 \\
(28.09)\end{array}$ \\
\hline Fourth quartile (highest) & $\begin{array}{l}59,399 \\
(33.12)\end{array}$ & $\begin{array}{l}13,613 \\
(29.68)\end{array}$ & $\begin{array}{l}14,854 \\
(31.96)\end{array}$ & $\begin{array}{l}14,997 \\
(33.66)\end{array}$ & $\begin{array}{l}15,935 \\
(37.53)\end{array}$ \\
\hline
\end{tabular}

Abbreviations: $\mathrm{N}$, number of people; SD, standard deviation

aUrban green space coverage was defined as the area of parks and artificially designed green space divided by the area of residential districts. 
Total Urban green space coverage ${ }^{a}$

\begin{tabular}{|c|c|c|c|c|c|}
\hline & & $\begin{array}{l}\text { First } \\
\text { quartile } \\
\text { (Low) }\end{array}$ & $\begin{array}{l}\text { Second } \\
\text { quartile }\end{array}$ & $\begin{array}{l}\text { Third } \\
\text { quartile }\end{array}$ & $\begin{array}{l}\text { Fourth } \\
\text { quartile (High) }\end{array}$ \\
\hline \multicolumn{6}{|c|}{$\begin{array}{l}\text { Charlson comorbidity index, } \\
\text { N (\%) }\end{array}$} \\
\hline 0 & $\begin{array}{l}105,253 \\
(58.69)\end{array}$ & $\begin{array}{l}26,367 \\
(57.49)\end{array}$ & $\begin{array}{l}27,211 \\
(58.55)\end{array}$ & $\begin{array}{l}26,461 \\
(59.39)\end{array}$ & $\begin{array}{l}25,214 \\
(59.39)\end{array}$ \\
\hline 1 & $\begin{array}{l}47,849 \\
(26.68)\end{array}$ & $\begin{array}{l}12,478 \\
(27.21)\end{array}$ & $\begin{array}{l}12,449 \\
(26.79)\end{array}$ & $\begin{array}{l}11,831 \\
(26.55)\end{array}$ & $\begin{array}{l}11,091 \\
(26.12)\end{array}$ \\
\hline$\geq 2$ & $\begin{array}{l}26,249 \\
(14.64)\end{array}$ & $\begin{array}{l}7,019 \\
(15.30)\end{array}$ & $\begin{array}{l}6,816 \\
(14.67)\end{array}$ & $\begin{array}{l}6,262 \\
(14.05)\end{array}$ & $6,152(14.49)$ \\
\hline \multicolumn{6}{|c|}{ Disability (\%) } \\
\hline Normal & $\begin{array}{l}168,837 \\
(94.14)\end{array}$ & $\begin{array}{l}43,040 \\
(93.84)\end{array}$ & $\begin{array}{l}43,747 \\
(94.13)\end{array}$ & $\begin{array}{l}41,940 \\
(94.13)\end{array}$ & $\begin{array}{l}40,110 \\
(94.47)\end{array}$ \\
\hline Mild & $\begin{array}{l}2,704 \\
(1.51)\end{array}$ & $\begin{array}{l}739 \\
(1.61)\end{array}$ & $\begin{array}{l}672 \\
(1.45)\end{array}$ & $\begin{array}{l}702 \\
(1.58)\end{array}$ & $591(1.39)$ \\
\hline Serious & $\begin{array}{l}7,810 \\
(4.35)\end{array}$ & $\begin{array}{l}2,085 \\
(4.55)\end{array}$ & $\begin{array}{l}2,057 \\
(4.43)\end{array}$ & $\begin{array}{l}1,912 \\
(4.29)\end{array}$ & $1,756(4.14)$ \\
\hline \multicolumn{6}{|c|}{ Abbreviations: $\mathrm{N}$, number of people; SD, standard deviation } \\
\hline
\end{tabular}


Table 2

Association of urban green space coverage with the risk of Alzheimer's disease

\begin{tabular}{|c|c|c|c|c|c|c|}
\hline & & \multicolumn{4}{|c|}{ Urban green space coverage ${ }^{a}$} & \multirow{2}{*}{$\begin{array}{l}\mathrm{p} \text { for } \\
\text { trend }\end{array}$} \\
\hline & & $\begin{array}{l}\text { First } \\
\text { quartile } \\
\text { (Low) }\end{array}$ & $\begin{array}{l}\text { Second } \\
\text { quartile }\end{array}$ & $\begin{array}{l}\text { Third } \\
\text { quartile }\end{array}$ & $\begin{array}{l}\text { Fourth quartile } \\
\text { (High) }\end{array}$ & \\
\hline \multirow[t]{3}{*}{$\begin{array}{l}\text { Alzheimer's } \\
\text { Disease }\end{array}$} & $\begin{array}{l}\text { Events, } \mathrm{N} \\
(\%)\end{array}$ & 428 & 380 & 366 & 325 & \\
\hline & $\begin{array}{l}\text { Person- } \\
\text { years }\end{array}$ & 346,408 & 353,584 & 339,243 & 324,505 & \\
\hline & $\begin{array}{l}\text { aHR } \\
(95 \% \mathrm{Cl})\end{array}$ & $\begin{array}{l}1.00 \\
\text { (Reference) }\end{array}$ & $\begin{array}{l}0.98(0.84- \\
1.14)\end{array}$ & $\begin{array}{l}0.96(0.82- \\
1.11)\end{array}$ & $\begin{array}{l}0.84(0.72- \\
0.99)\end{array}$ & 0.045 \\
\hline \multicolumn{7}{|c|}{ Abbreviations: $\mathrm{N}$, number of people; aHR, adjusted hazard ratio; $\mathrm{Cl}$, confidential interval } \\
\hline \multicolumn{7}{|c|}{$\begin{array}{l}\text { aUrban green space coverage was defined as the area of parks and artificially designed green space } \\
\text { divided by the area of residential districts. }\end{array}$} \\
\hline
\end{tabular}


Table 3

Stratified analysis on the association of urban green space coverage with the risk of Alzheimer's disease

\begin{tabular}{|c|c|c|c|c|c|c|}
\hline & & \multicolumn{5}{|c|}{ Urban green space coverage ${ }^{a}$} \\
\hline & & $\begin{array}{l}\text { First } \\
\text { quartile } \\
\text { (Low) }\end{array}$ & $\begin{array}{l}\text { Second } \\
\text { quartile }\end{array}$ & $\begin{array}{l}\text { Third } \\
\text { quartile }\end{array}$ & $\begin{array}{l}\text { Fourth } \\
\text { quartile } \\
\text { (High) }\end{array}$ & $\begin{array}{l}p \text { for } \\
\text { trend }\end{array}$ \\
\hline \multirow[t]{2}{*}{$\begin{array}{l}\text { Age } \\
\text { aHR } R^{b}(95 \% \\
\mathrm{Cl})\end{array}$} & $40-64$ & $\begin{array}{l}1.00 \\
\text { (Reference) }\end{array}$ & $\begin{array}{l}0.80 \\
(0.61- \\
1.04)\end{array}$ & $\begin{array}{l}0.98 \\
(0.76- \\
1.27)\end{array}$ & $\begin{array}{l}0.81(0.62- \\
1.07)\end{array}$ & 0.341 \\
\hline & $65-74$ & $\begin{array}{l}1.00 \\
\text { (Reference) }\end{array}$ & $\begin{array}{l}1.07 \\
(0.89- \\
1.29)\end{array}$ & $\begin{array}{l}0.93 \\
(0.76- \\
1.12)\end{array}$ & $\begin{array}{l}0.86(0.70- \\
1.04)\end{array}$ & 0.070 \\
\hline \multirow[t]{2}{*}{$\begin{array}{l}\text { Sex } \\
\text { aHR } R^{b}(95 \% \\
\text { Cl) }\end{array}$} & Men & $\begin{array}{l}1.00 \\
\text { (Reference) }\end{array}$ & $\begin{array}{l}0.97 \\
(0.75- \\
1.26)\end{array}$ & $\begin{array}{l}0.84 \\
(0.64- \\
1.11)\end{array}$ & $\begin{array}{l}0.81(0.61- \\
1.07)\end{array}$ & 0.080 \\
\hline & Women & $\begin{array}{l}1.00 \\
\text { (Reference) }\end{array}$ & $\begin{array}{l}0.97 \\
(0.80- \\
1.16)\end{array}$ & $\begin{array}{l}0.99 \\
(0.83- \\
1.20)\end{array}$ & $\begin{array}{l}0.85(0.70- \\
1.03)\end{array}$ & 0.164 \\
\hline \multirow{2}{*}{$\begin{array}{l}\text { Household } \\
\text { income } \\
\mathrm{aHR}^{\mathrm{b}}(95 \% \\
\mathrm{Cl})\end{array}$} & $\begin{array}{l}\text { Lower } \\
\text { half }\end{array}$ & $\begin{array}{l}1.00 \\
\text { (Reference) }\end{array}$ & $\begin{array}{l}0.90 \\
(0.71- \\
1.14)\end{array}$ & $\begin{array}{l}0.99 \\
(0.79- \\
1.25)\end{array}$ & $\begin{array}{l}0.89(0.70- \\
1.14)\end{array}$ & 0.521 \\
\hline & $\begin{array}{l}\text { Upper } \\
\text { half }\end{array}$ & $\begin{array}{l}1.00 \\
\text { (Reference) }\end{array}$ & $\begin{array}{l}1.03 \\
(0.84- \\
1.25)\end{array}$ & $\begin{array}{l}0.91 \\
(0.74- \\
1.11)\end{array}$ & $\begin{array}{l}0.80(0.65- \\
0.99)\end{array}$ & 0.027 \\
\hline \multirow[t]{2}{*}{$\begin{array}{l}\mathrm{CCl} \\
\text { aHR } \mathrm{R}^{\mathrm{b}}(95 \% \\
\mathrm{Cl})\end{array}$} & 0 & $\begin{array}{l}1.00 \\
\text { (Reference) }\end{array}$ & $\begin{array}{l}0.96 \\
(0.75- \\
1.24)\end{array}$ & $\begin{array}{l}0.96 \\
(0.72- \\
1.24)\end{array}$ & $\begin{array}{l}0.95(0.73- \\
1.24)\end{array}$ & 0.701 \\
\hline & $\geq 1$ & $\begin{array}{l}1.00 \\
\text { (Reference) }\end{array}$ & $\begin{array}{l}0.97 \\
(0.81- \\
1.17)\end{array}$ & $\begin{array}{l}0.93 \\
(0.77- \\
1.13)\end{array}$ & $\begin{array}{l}0.78(0.64- \\
0.96)\end{array}$ & 0.021 \\
\hline \multirow[t]{2}{*}{$\begin{array}{l}\text { Disability } \\
\text { aHR } \mathrm{R}^{\mathrm{b}}(95 \% \\
\mathrm{Cl})\end{array}$} & Normal & $\begin{array}{l}1.00 \\
\text { (Reference) }\end{array}$ & $\begin{array}{l}0.93 \\
(0.80- \\
1.10)\end{array}$ & $\begin{array}{l}0.91 \\
(0.77- \\
1.07)\end{array}$ & $\begin{array}{l}0.82(0.69- \\
0.97)\end{array}$ & 0.022 \\
\hline & Abnormal & $\begin{array}{l}1.00 \\
\text { (Reference) }\end{array}$ & $\begin{array}{l}1.30 \\
(0.84- \\
2.04)\end{array}$ & $\begin{array}{l}1.28(0.82- \\
2.00)\end{array}$ & $\begin{array}{l}0.98(0.60- \\
1.61)\end{array}$ & 0.967 \\
\hline \multicolumn{7}{|c|}{ Abbreviation: aHR, adjusted hazard ratio; $\mathrm{Cl}$, confidential interval } \\
\hline \multicolumn{7}{|c|}{$\begin{array}{l}\text { aUrban green space coverage was defined as the area of parks and artificially designed green space } \\
\text { divided by the area of residential districts. }\end{array}$} \\
\hline
\end{tabular}


Table 4

Sensitivity analysis on the association of urban green space coverage with the risk of Alzheimer's disease $^{a}$

\begin{tabular}{|c|c|c|c|c|c|c|}
\hline & & \multicolumn{4}{|c|}{ Urban green space coverage $\mathrm{e}^{\mathrm{b}}$} & \multirow{2}{*}{$\begin{array}{l}p \text { for } \\
\text { trend }\end{array}$} \\
\hline & & $\begin{array}{l}\text { First } \\
\text { quartile } \\
\text { (Low) }\end{array}$ & $\begin{array}{l}\text { Second } \\
\text { quartile }\end{array}$ & Third quartile & $\begin{array}{l}\text { Fourth quartile } \\
\text { (High) }\end{array}$ & \\
\hline \multirow[t]{3}{*}{$\begin{array}{l}\text { Alzheimer's } \\
\text { Disease }\end{array}$} & $\begin{array}{l}\text { Events, } \\
\mathrm{N}(\%)\end{array}$ & 428 & 380 & 366 & 325 & \\
\hline & $\begin{array}{l}\text { Person- } \\
\text { years }\end{array}$ & 346,408 & 353,584 & 339,243 & 324,505 & \\
\hline & $\begin{array}{l}\mathrm{aHR}^{\mathrm{c}} \\
(95 \% \mathrm{Cl})\end{array}$ & $\begin{array}{l}1.00 \\
\text { (Reference) }\end{array}$ & $\begin{array}{l}0.97(0.82- \\
1.16)\end{array}$ & $\begin{array}{l}0.89(0.75- \\
1.07)\end{array}$ & $\begin{array}{l}0.83 \\
(0.69- \\
1.00)\end{array}$ & 0.038 \\
\hline
\end{tabular}

\section{Supplementary Files}

This is a list of supplementary files associated with this preprint. Click to download.

- SupplementaryTables1.docx 